\title{
Pasca Kondisi Implementasi Akuntansi Berbasis Akrual Pada Penyusunan Laporan Keuangan Kementerian Keuangan: Studi Etnometodologi
}

\author{
Syahril Djaddang1, Devi Kusumawardhani ${ }^{2}$ \\ ${ }^{1}$ Universitas Pancasila , Jakarta \\ 2 STIES, Jakarta
}

INFO ARTIKEL

JEL Classification : H83, G02

\begin{abstract}
This research is qualitative research with etnomethodology approach, whereas researcher seeking the deeper meaning behind the accountancy numerals. The aim of this research is to recite the condition after accountancy accrual basis implementation in finansial record compiling at the finance ministry. Decision of Government Regulation No.71 2010 regarding Government entities to adapt and to face the challenging accountancy accrual basis implementation. Data collection was conducted with interview, filed notes, and documentation. The result of this research financial report compiling at the finance ministry. The result of this research indicated that finance ministry success to defend the unqualified opinion WTP (unqualified opinion) however, still needed stage in implementation fully to obey the government accountancy standard. There are constraint yet in accountancy technical, asset problems, in complexity understanding, human resources coordination, application problems unfully accrual basis, internal control implementation, and increment or the change of accountancy policy to decide accrual point in several the addition of theory namely Theory of Change and the Theory of Role. Theory of Change and the Theory of Role $U A P A$ is relevant to recite the deeper meaning in this research. UAPA (accounting units of budget users) in financial ministry has an important role, as Detailer Government Accountancy Standard, Consultant Accountancy Units, Business Process Catalyst, and Locomotive Accountancy Units.
\end{abstract}

\begin{abstract}
ABSTRAK
Penelitian ini penelitian kualitatif dengan pendekatan etnometodologi, dimana peneliti mencari kedalaman makna dibalik angka-angka akuntansi. Tujuan penelitian ini untuk mengkaji Pasca Kondisi Implementasi Akuntansi Berbasis Akrual Pada Penyusunan Laporan Keuangan di Kementerian Keuangan. Penetapan Peraturan Pemerintah Nomor 71 tahun 2010 tentang Standar Akuntansi Pemerintah membawa konsekuensi bagi Entitas Pemerintah untuk menyesuaikan tantangan implementasi akuntansi berbasis akrual. Pengumpulan data dengan melakukan interview, membuat field notes, serta dokumentasi. Hasil penelitian menunjukkan
\end{abstract}

\footnotetext{
* Email Korespondensi: ${ }^{1}$ djaddangsyahril@gmail.com
} 
Kementerian Keuangan berhasil mempertahankan

\section{Pendahuluan}

Reformasi pengelolaan keuangan negara direfleksikan dengan lahirnya UU Nomor 17 Tahun 2003 tentang Keuangan Negara, UU Nomor 1 Tahun 2004 tentang Perbendaharaan Negara, dan UU Nomor 15 Tahun 2004 tentang pemeriksaan pengelolaan dan tanggungjawab keuangan Negara (Achmad, 2015). Ranah sektor publik memerlukan basis akuntansi yang tepat. Pemerintah menetapkan Peraturan Pemerintah Nomor 71 tahun 2010 berisi Standar Akuntansi Pemerintahan (SAP) berbasis akrual. Negara pendonor menekan Indonesia untuk mengadopsi IPSAS (International Public Sector Accounting Standards). Memenuhi ketentuan Internasional perlu pemahaman rumit dan biaya sosialisasi mahal.

Komite Standar Akuntansi Pemerintahan sebagai penyusun SAP melakukan harmonisasi mengacu pada IPSAS, dengan merespon kondisi tekanan nasional, politik, sosial, dan ekonomi. Basis akrual mengakui transaksi pada periode saat terjadi juga lebih informatif menggambarkan seluruh sumber daya. Penerapannya memerlukan biaya besar untuk jasa penilai, kebijakan akuntansi, system akuntansi, hardware, dan sumber daya manusia memadai untuk berakrualisasi (IFAC No.14, 2003). Bukan hanya menyangkut masalah teknis akuntansi, tetapi membutuhkan perubahan budaya organisasi. SAP belum mengatur detail mekanisme akuntansi atas bisnis proses peristiwa akuntansi yang terjadi.

Kementerian Keuangan sebagai pilot project akrualisasi menjadi bahan sosialisasi ke instansi pemerintah lain. Menteri Keuangan berperan sebagai Bendahara Umum Negara (BUN) berwenang menetapkan Sistem Akuntansi dan Pelaporan Keuangan Negara, sedangkan sebagai Pengguna Anggaran wajib menyusun Laporan Keuangan Pemerintah Pusat (LKPP), Laporan Keuangan Bendahara Umum Negara (LKBUN), dan Laporan Keuangan Kementerian/Lembaga (LKKL). Kementerian Keuangan berhasil mempertahankan perolehan opini WTP dari BPK, sejak tahun 2011-2016. Ada beberapa temuan BPK dengan nilai yang tidak material. Masih banyak kasus spesifik terkait perlakuan titik kritis akrualisasi dari masing-masing bisnis proses, menjadi tantangan bagi para penyusun Laporan Keuangan untuk membuat kesepakatan. Rentang kendali Kementerian Keuangan sejumlah 1100 Satuan Kerja, dengan keanekaragaman kompetensi SDM dengan permasalahan yang berbeda.

Penelitian terdahulu yang berkaitan penerapan akuntansi berbasis akrual seperti Lestari (2014), Ida Najati dan Edar Pituringsih (2016), Nyoman Triyadi Agustiawan (2016), Etika Sari (2017), Ezra Paula Mentu dan Jullie J. Sondakh (2016), serta Wahyu Purwanto (2015) menunjukkan bahwa mengadopsi basis 
akrual membutuhkan waktu dan lebih rumit. Tantangan implementasi berbasis akrual tidak luput dari Sistem Pengendalian Intern, Pemanfaatan Teknologi Informasi, dan Kompetensi Sumber Daya Manusia. Kualitas Sumber Daya Manusia yang handal dapat menghasilkan kesepakatan-kesepakatan kebijakan internal akuntansi dan menghasilkan Laporan Keuangan yang berkualitas.

Adanya interaksi akuntansi dalam lingkungan sosialnya dalam pengambilan keputusan akuntansi, memotivasi peneliti untuk mencari kedalaman makna dibalik angka-angka akuntansi. Memotret bagaimana dinamika sebuah organisasi sektor public atas kesadaran para penyusun laporan keuangan dan kesepakatan mereka harus beradaptasi dan membumikanmhadirnya Peraturan Pemerintah Nomor 71 tahun 2010. Adapun masalah pada penelitian ini, adalah "Bagaimana Mengkaji Pasca Kondisi Implementasi Akuntansi Berbasis Akrual Pada Penyusunan Laporan Keuangna Di Kementerian Keuangan?"

\section{Metode Penelitian}

Metode penelitian yang menjabarkan proses pencarian sociological reasoning yang meliputi diri informan, kesadaran mendalam informan, dan kesepakatan kelompok informan yaitu metodologi kualitatif dengan pendekatan Etnometodologi (Neuman,2016). Pendekatan Etnometodologi digunakan agar peneliti mengetahui bagaimana proses pasca kondisi secara pemahaman lebih mendalam mulai dibumikannya PP Nomor 71 tahun 2010. Ethnomethodological studies are ot directed to formulating or arguing correctives They do not formulate remedies for practical actions" (Garfinkel 1967:viii).

Studi etnometodologi fokus pada pencarian makna aktivitas keseharian yang disepakati oleh anggota komunitas, melalui beberapa tahapan analisis ekspresi indeksikalitas, analisis refleksivitas, dan common sense knowledge of social structures. Menurut regulasi yang mengatur mengenai penyusunan laporan keuangan di tingkat Kementerian/Lembaga yaitu Peraturan Menteri Keuangan Nomor 222/PMK.05/2016 tentang Pedoman Penyusunan Laporan Keuangan Kementerian/Lembaga. Dalam pelaksanaan tugas dan fungsi tersebut oleh Unit Akuntansi dan Pelaporan Akuntansi terdiri dari Penanggung jawab UAPA (Unit Akuntansi Pengguna Anggaran) dan Petugas Akuntansi. Penanggung jawab UAPA yaitu : Menteri/ Pimpinan Lembaga, Pejabat eselon I dan Kepala Biro yang membidangi keuangan (eselon II), Kepala Bagian Keuangan (eselon III) dan Kepala Subbagian Keuangan (eselon IV).

Sesuai dengan pendekatan etnometodologi yang digunakan dalam penelitian ini, maka cara pengumpulan data dilakukan dengan cara melakukan wawancara (interview), membuat catatan lapangan (field notes) dari pengamatan partisipan, serta dokumentasi.

Wawancara dalam penelitian dimulai dari wawancara pembicaraan informal spontanitas, kemudian menggunakan petunjuk kerangka garis besar wawancara baku. Informan yang dipilih adalah para penyusun laporan keuangan Kementerian Keuangan yaitu pegawai negeri sipil yang merupakan pimpinan dan staf akuntansi penyusun laporan keuangan di tingkat Unit Akuntansi Pengguna Anggaran. Analisis dari hasil wawancara untuk memahami secara rinci struktur fundamental interaksi melalui percakapan. Aktivitas interaksi yang menunjukkan aktivitas stabil merupakan kegiatan yang dapat dianalisis.

Catatan Lapangan ini mencakup semua fenomena yang teramati selama pengamatan berlangsung. Himpunan data berupa catatan rinci terdiri dari:

1. Jotted Notes (catatan yang dibuat ditempat penelitian untuk mengingatkan memori).

2. Catatan Dari Pengamatan Langsung (catatan setelah meninggalkan tempat peneliti disusun secara kronologis).

3. Catatan Intrepretasi Peneliti (catatan intrepretasi peneliti tentang obyek penelitian).

4. Catatan Analitis (menulis taktik, rencana, kritikan pribadi mengenai keputusan yang diambil sendiri).

5. Catatan Pribadi (catatan pribadi peneliti mengenai hal yang peneliti rasakan selama penelitian).

6. Peta dan Diagram (berperan menggambarkan situasi di tempat penelitian). 
7. Rekaman video atau suara (catatan mengingat percakapan dan kejadian pada tahap wawancara)

Peneliti dapat menggunakan dokumendokumen yang dihasilkan dari aktivitasaktivitas yang dilakukan oleh obyek penelitian baik berupa laporan, peraturan kebijakan, dokumen publik ataupun dokumen privat (Creswell, 2014). Dokumen yang dijadikan sebagai bukti pendukung penelitian ini antara lain:

1. Peraturan Menteri Keuangan mengenai pelaporan keuangan, digunakan untuk mengetahui ketentuan pelaksanaan pelaporan keuangan Kementerian/Lembaga.

2. Peraturan Dirjen Perbendaharaan mengenai pelaporan keuangan, digunakan untuk mengetahui tata cara pelaporan keuangan dan pihak-pihak yang terkait.

3. Surat Edaran Menteri Keuangan mengenai petunjuk teknis akuntansi pendapatan digunakan untuk mengetahui kebijakan akutansi yang digunakan Kementerian Keuangan.

4. Laporan Keuangan Kementerian Keuangan yang telah diaudit, digunakan untuk mengetahui bentuk dan kelengkapan laporan keuangan yang telah disusun.

5. Laporan Hasil Pemeriksaan BPK RI tahun 2015-2016, digunakan untuk mengetahui detail kelemahan penyajian nilai akrual Kementerian Keuangan.

6. Standar Operasional Prosedur, digunakan untuk membantu mengetahui gambaran proses bisnis notulen rapat, digunakan untuk membantu mengetahui perkembangan pelaporan keuangan.

Analisa data study etnometodologi dilakukan sejak proses pengumpulan data. Aktivitas dalam analisis data, yaitu data reduction, data display, dan concslusion drawing/verification. Langkah-langkah analisis ditunjukkan pada gambar berikut :

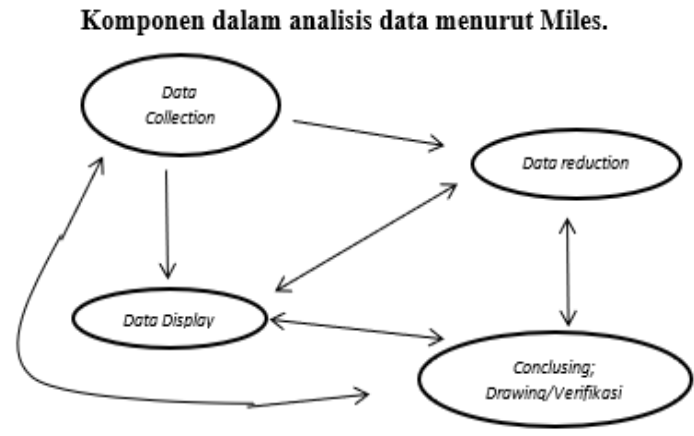

Sumber : Alfabeta ( Prof. Dr. Sugiyono)

Mengacu Sugiyono (2009), langkahlangkah yang ditempuh adalah :

a. Data Reduction (Reduksi Data)

Reduksi data menggunakan eksplanasi yang menurut Yin (2013) adalah penjelasan tentang kasus yang bersangkutan untuk menjawab pertanyaan-pertanyaan penelitian yang diajukan. Pengorganisasian data dilakukan dengan membagi berdasarkan periode waktu penyusunan laporan keuangan untuk memudahkan analisis data, sebagai berikut:

- Pra Penyusunan Laporan Keuangan

- Penyusunan Laporan Keuangan Unaudited

- Penyusunan Laporan Keuangan Audited

b. Data Display (Penyajian Data)

Setelah data direduksi, maka langkah selanjutnya adalah mendisplaykan data. Penyajian data dalam penelitian kualitatif adalah teks yang bersifat naratif. Dengan mendisplaykan data memudahkan memahami apa yang terjadi, merencanakan kerja selanjutnya berdasarkan apa yang telah dipahami tersebut.

\section{c. Conclusion Drawing/Verification}

Yaitu tahapan melakukan penarikan kesimpulan dan verifikasi. Pengujian kredibilitas data penelitian dilakukan dengan cara :

\section{Perpanjang pengamatan}

Apabila data yang diperoleh dirasa belum kredibel fokus terjawab melalui data.

2. Meningkatkan ketekunan

Pengujian kredibilitas dilakukan peneliti dengan membaca seluruh catatan hasil penelitian secara cermat, sehingga dapat diketahui kesalahan dan kekurangannya. 
3. Diskusi Teman Sejawat

Diskusi teman sejawat dilakukan dengan mendiskusikan hasil penelitian yang masih bersifat sementara kepada mahasiswa S2 dan S3.

4. Analisis Kasus Negatif

Melakukan analisis kasus negatif berarti peneliti mencari data yang berbeda atau bahkan bertentangan dengan data yang telah ditemukan. Bila tidak ada lagi data yang berbeda atau yang bertentangan dengan temuan, berarti data yang ditemukan sudah dapat dipercaya.

5. Triangulasi

Triangulasi teknik adalah teknik pemeriksaan keabsahan data yang dilakukan dengan teknik wawancara, observasi, dan dokumentasi. Triangulasi sumber dengan menanyakan hal yang sama melalui sumber data yang berbeda. Triangulasi waktu artinya pengumpulan data dilakukan pada berbagai kesempatan berbagai waktu. (Sugiyono, 2009). Triangulasi mengkaji fenomena yang saling terkait dari sudut pandang dan perspektif yang berbeda.

6. Member check (Pengecekan anggota)

Pengujian kredibilitas data dengan member check, dilakukan dengan cara mendiskusikan hasil penelitian kepada sumber-sumber data yang valid, sehingga dapat diketahui apakah mereka merasa bahwa laporan/deskripsi/tema tersebut sudah akurat (Creswell, 2014).

\section{Hasil Penelitian dan Pembahasan}

Dalam tahapan analisis studi etnometodologi yaitu komunitas, tahapan awalnya adalah pemilihan komunitas pada Unit Akuntansi dan Pengguna Anggaran di Kementerian Keuangan yang memproduksi Laporan Keuangan Kementerian/Lembaga.

\section{Intepretasi Hasil Penelitian}

Pasca kondisi Kementerian Keuangan sebagai pilot projek membumikan PP Nomor 71 tahun 2010, membuahkan opini WTP dari BPK dari tahun 2011-2016. UAPA sejak tahun anggaran 2015, telah melaksanakan tanggungjawabnya, memantau pelaksanaan system akuntansi dan pelaporan keuangan pada unit-unit akuntansi di lingkungan Kementerian Keuangan. Para Penyusun
Laporan Keuangan tingkat UAPA mempunyai peranan yang kuat dalam memproduksi aktivitas kesehariannya merealisasikan implementasi basis akrual. Metode Etnometodologi telah merekam perubahanperubahan yang terjadi tanpa harus menyadarkan diri pada ingatan partisipan. Usai jam kerja Kepala Bagian Akuntansi dan Pelaporan Keuangan, Kepala Sub Bagian Akuntansi dan Pelaporan Keuangan, Penelaah Laporan Keuangan, Tim Sistem Informasi Akuntansi, dan Staf lainnya selalu rutin rapat evaluasi harian. Hal ini menunjukkan telah tumbuhnya kebersamaan dan keefektifan tim di tingkat UAPA.

Karakteristik dan tipe pemimpin tingkat UAPA dalam memahami perannya yaitu :

1. Kepala Biro Perencanaan dan Keuangan merupakan sosok pemimpin yang perfeksionis dan selalu menghimbau staf untuk tepat sasaran pada setiap pekerjaan.

2. Kepala Bagian Akuntansi dan Pelaporan Keuangan bertipe pemimipin paternalistik dan demokratis.

3. Kepala Sub Bagian Akuntansi dan Pelaporan Keuangan I mempunyai kharisma, dedikasi tinggi, volunteer, persiapan ekstra sense of urgency untuk menghadapi staf-stafnya, dan memberikan stimulasi motivasi.

4. Kepala Sub Bagian Akuntansi dan Pelaporan Keuangan II adalah sosok yang sederhana, rutinitas, dan sekedar menggugurkan kewajiban bekerja.

5. Kepala Sub Bagian Akuntansi dan Pelaporan Keuangan III adalah sosok luwes, loyalitas tinggi, dan mengikuti perkembangan ilmu pengetahuan.

6. Kepala Sub Bagian Akuntansi dan Pelaporan Keuangan IV merupakan sosok supel, antusias, dan sensitive pada hambatan.

7. Pelaksana Penelaah Laporan Keuangan merupakan sosok yang rutinitas dan disiplin jadwal kegiatan.

8. Tim Sistem Informasi Akuntansi merupakan sosok yang kritis, emosional, dan handal menguasai tehnologi dan pengetahuan akuntansi.

Hasil interpretasi peneliti menunjukkan pimpinan telah menunjukkan pimpinan telah memenuhi komitmennya menghadapi tantangan akrualisasi, namun masih perlu 
penyesuaian yang tinggi dan tantangan dalam mengadopsinya. Dikaji dari hasil penelitian, basis akrual pengenalannya sulit dilakukan, perlu pemahaman yang lebih kompleks. Peneliti menemukan beberapa permasalahan dan tantangan yang terjadi dalam dua tahun ini sebagai berikut :

1. Beban bagi Sumber Daya Manusia harus menyesuaikan dengan basis akrual dengan keseragaman pemahaman yang sama.

2. Bagi UAPA kesulitan mengarahkan SDM dalam tugasnya jadi berulang-ulang karena pola mutasi rolling pegawai terlalu cepat.

3. Pencatatan yang belum teratur untuk transfer masuk, transfer keluar, piutang pajak, pembayaran pihak ketiga, dan piutang PBB.

4. Dokumen SOP yang dihasilkan sebagian belum ada.

5. Persediaan Bea Cukai cukup banyak belum dikelola dengan baik.

6. Indentifikasi asset tetap, banyak yang hilang.

7. Aplikasi yang disosialisasikan belum sempurna, masih banyak yang belum bisa diterapkan untuk basis akrual penuh.

8. Tingkat Sistem Pengendalian Intern belum diterapkan hanya mengandalkan kertas kerja berupa Berita Acara rekonsiliasi belanja, kas, belanja modal, mutasi asset, penerimaan, pendapatan bukan pajak, dan piutang. Ada lagi Kertas Kerja Telaah Laporan Keuangan.

9. Beberapa kebijakan akuntansi belum terinci dan belum spesifik, sehingga beberapa kasus akuntansi yang membutuhkan perlakuan khusus muncul, yang akhirnya diselesaikan dengan kesepakatan UAPA.

- Pendapatan bea lelang yang batal atas permintaan penjual.

- Kesepakatan penyesuaian laporan keuangan atas beberapa peristiwa yang terjadi antara akhir periode laporan dan tanggal ketika keuangan diotorisasi untuk terbit.

- Kasus-kasus pendapatan BLU, Pendapatan Pajak, dan Pendapatan Bea Cukai membutuhkan titik kritis akrualisasinya sendiri-sendiri.

- Permasalahan yang terjadi adalah PNBP yang tidak sesuai institusi dan pendapatan pajak dari potongan SPM yang belum dikoreksi, karena input manual Satker di aplikasi SAS.

- Permasalahan belum ada dokumen penetapan piutang tp/tgr.

- Terjadi selisih pada transaksi KDP antara hasil SAIBA dan hasil SIMAK.

10. Masih ada celah-celah ketidaksesuaian dengan SAP karena penyesuaian yang tinggi membutuhkan tahapan dan sebagian karena SPI nya lemah.

11. Sosialisasi kebijakan akuntansi maupun aplikasi berbenturan dengan periode berakhirnya Penyusunan Laporan Keuangan.

\section{Interpretasi Temuan Teori}

Peneliti menemukan teori yang relevan dengan penelitian ini, yang dapat membantu mengkaji makna lebih dalam. Akuntansi berbasis akrual memang jauh lebih kompleks dibanding cash basis, sejalan dengan perubahan fundamental bisnis proses penyusunan laporan keuangan dan dukungan tehnologi informasi yang bertahap. Hal ini bukan hanya masalah teknis akuntansi saja, tetapi membutuhkan perubahan budaya para penyusun laporan keuangan. Kurt Lewin mengemukakan pendekatan force-field model dalam perubahan di tahun 1964. By (2005) mendefinisikan manajemen perubahan yaitu :

"Manajemen perubahan adalah proses yang secara kontinue membuat pembaharuan dalam arah, struktur, dan kemampuan organisasi dalam melayani perubahan tiada henti dari pelanggan eksternal maupun internal".

Sembiring (2009) menjelaskan tahap kesuksesan suatu perubahan sebagai berikut:

1. Unfreezing the present level adalah pencairan kebiasaan kerja yang selama ini diterapkan karyawan dan sudah merasa nyaman dengan kebiasaan tersebut, Moving to the new level digambarkan sebagai pelaksanaan perubahan yang harus menuju ke suatu titik sebagai tujuan perubahan, Refreezing this new level dijelaskan harus membekukan kembali perubahan yang telah berjalan dengan cara dibudayakan dalam organisasi.

2. Pergeseran struktur berorientasi akrual yang komprehensif atas akuntansi dan pelaporan keuangan salah satunya 
mengandalkan komitmen pimpinan dan type pemimpin yang sinkron dengan kondisi penyesuaian. Menurut saya, hal krusial adalah bagaimana para actor Penyusun Laporan Keuangan menyesuaikan diri mengolah rasa dan mengubah perilaku lama dengan fenomena adanya peraturan baru yang lebih rumit. Manusia merupakan makhluk yang terikat oleh kebiasaan. Realitasnya setelah pasca kondisi mulai diterapkan PP nomor 71 th 2010 dan turunannya di dalam institusi kementerian/lembaga belum terlalu siap dihadapi sebagian besar orang, dari perubahan memerinci pengetahuan dari cash basis ke accrual basis masih ada kendala salah persepsi dan belum semuanya sepaham. Belum lagi bagaimana perubahan sikap harus loyal menerima akrualisasi yang lebih rumit juga ada tambahan jadwal evaluasi dari pimpinan di luar jam kerja serta kemampuan sosialisasi ke unit-unit akuntansi dibawahnya sedangkan pola mutasi tidak beraturan. Perubahan tidak dapat dicapai sekejap memerlukan kesadaran masing-masing actor yang harus selalu dibangun baik oleh pimpinan maupun rekan kerja supaya ada kesatuan langkah. Demikian hukum alam perubahan "tantangan selalu menjadi kawan dari perubahan". Penelitian ini relevan dengan Teori Perubahan Pasca Kondisi Implementasi Basis Akrual.

3. Akuntansi Keperilakuan membahas bagaimana akuntansi dan perilaku manusia dalam suatu organisasi saling mempengaruhi dan berinteraksi. (Dr. I Wayan Suartana, 2006). Role theory mendefinisikan peran sebagai "the boundaries and sets of expectations applied to role incumbents of a particular position, wich are determined by the role incumbent and the role senders within and beyond the organization's boundaries" (Banton, 1965; Katz \& Kahn, 1966, dalam Bauer, 2003: 54). Selain itu, Robbins (2001:227) mendefinisikan peran sebagai " a set of expected behavior pattern attributed to someone occupying a given position in a social unit". Peran itu berkaitan dengan perilaku yang diharapkan dalam suatu pekerjaan dan menghasilkan beberapa perubahan perilaku utama. Bagaimana orang memposisikan dirinya dan bagaimana tindakan yang dipilih saat melakukan interaksi dengan orang lain dalam suatu institusi.

4. Teori peran merupakan interaksi antara peran sosial (social role), norma (norms), dan identitas (identity) atas orang-orang yang ada di dalam suatu organisasi. (Soekanto, 2009). Peran sosial adalah kaitan dari hak, tugas, tanggung jawab, dan perilaku yang tepat dari orang-orang yang memiliki posisi tertentu dalam konteks sosial. Norma adalah perilaku yang dianggap tepat dan diharapkan dalam suatu peran tertentu. Sedangkan identitas adalah berkaitan dengan bagaimana seseorang menetapkan siapa dirinya dan bagaimana ia akan bertindak pada situasi tertentu. (Sarwono, 2002). UAPA Kementerian Keuangan berperan penting terhadap penyusunan laporan keuangan pemerintah, tidak hanya menyusun LKKL, LKBUN, dan LKPP. Interaksi antara actor, activity, dan place menghasilkan situasi sosial.

Menurut pengamatan dan kajian Peneliti ada beberapa peran yang harus bisa diperankan oleh aktor Penyusun Laporan Keuangan melihat dari tanggung jawab yang diembannya. Penelitian ini relevan menggunakan teori Peran Unit Akuntansi Pengguna Anggaran.

\section{Peran UAPA Sebagai Perinci Standar Akuntansi Pemerintah}

UAPA harus detail dalam pemahaman SAP berbasis Akrual dan Kebijakan Akuntansi yang diperlukan. Wawancara yang relevan pada pertanyaan, sebagai berikut:

1. Apa yang menjadi keunikan Kementerian Keuangan dibanding kementerian lain?

2. Bagaimana menentukan kebijakan akuntansi berbasis akrual?

3. Apakah ketika membuat kebijakan akuntansi internal, internal UAPA selalu sepakat?

4. Bagaimana mekanisme pengendalian intern yang diterapkan?

5. Bagaimana kerangka acuan waktu (cut off)? 
6. Bagaimana menentukan kesepakatan angka pada laporan keuangan audited?

7. SAP yang ada di Indonesia menurut masing masing penyusun Laporan Keuangan, apakah masih relevan di dunia Internasional dan mengacu pada negara mana?

\section{Peran UAPA Sebagai Konsultan}

Konsultan unit-unit akuntansi terkait pelaksanaan tugas dan fungsi masing-masing unit. Wawancara yang relevan pada pertanyaan, sebagai berikut:

1. Apa saja persiapan terkait SDM dalam menyusun laporan keuangan berbasis akrual?

2. Bagaimana Persiapan Satker dalam menyusun Laporan Keuangan?

3. Bagaimana kompetensi sumber daya manusia dalam penyusunan laporan keuangan

4. berbasis akrual?

5. Apa saja permasalahan penyusunan laporan keuangan berbasis akrual tingkat

6. kementerian?

7. Bagaimana UAPA mengatasi masalah tersebut?

\section{Peran UAPA Sebagai Katalisator Proses Bisnis}

UAPA mempercepat reaksi perubahan. Wawancara yang relevan pada pertanyaan, sebagai berikut:

1. Bagaimana dukungan teknologi dan sistem informasi dalam penyusunan laporan keuangan?

\section{UAPA Sebagai Lokomotif}

Lokomotif adalah rangkaian kereta api yang terdapat mesin untuk menggerakkan kereta api, kalau gerbong boleh lebih dari satu. Ibarat lokomotif, UAPA tidak boleh menentukan kebijakan akuntansi yang berbeda dalam satu peristiwa yang sama. Wawancara yang relevan pada pertanyaan, sebagai berikut:

1. Apa ketentuan terkait pelaporan keuangan saat ini sudah komprehensif?

2. Bagaimana Kementerian Keuangan beradaptasi terhadap perubahan basis akuntansi

3. menjadi akrual penuh?
4. Bagaimana UAPA bersikap atas adanya temuan pemeriksaan?

5. Bagaimana Kementerian Keuangan mempertahankan opini WTP?

\section{Kesimpulan, Keterbatasan dan Implikasi Hasil Penelitian}

Penelitian ini menghasilkan kesimpulan bahwa Kementerian Keuangan memerlukan peranan penting UAPA (Unit Akuntansi Pengguna Anggaran) mengatasi tantangan perubahan untuk implementasi basis Akrual. Walaupun telah mencapai opini WTP, namun masih belum terealisasi sepenuhnya kepatuhan menjalankan akuntansi berbasis akrual. Peneliti menemukan tambahan teori yaitu, teori Perubahan dan teori Peran yang relevan membantu mengkaji makna lebih dalam penelitian ini. UAPA Kementerian Keuangan ibarat berperan sebagai Perinci Standar Akuntansi Pemerintah, Konsultan unit-unit Akuntansi, Katalisator Proses Bisnis, dan Lokomotif Unit-Unit Akuntansi.

Sebagai upaya untuk implementasi Akuntansi berbasis Akrual di Kementerian Keuangan, disarankan adanya langkahlangkah maupun perubahan sebagai berikut:

1. Penyusun Laporan Keuangan memiliki komitmen yang kuat, konsisten, dan tanggungjawab untuk menjalankan kebijakan dan peraturan basis akrual yang sesuai PP nomor 71 tahun 2010.

2. Adanya penertiban pencatatan peristiwa akuntansi secara lengkap agar kualitasnya lebih handal.

3. Direkomendasikan penambahan jenis kertas kerja untuk kertas kerja transfer masuk, kertas kerja transfer keluar, dan kertas kerja penyusunan piutang PBB.

4. Segera dimulai penerapan SPI pada Kementerian Keuangan untuk meminimalisir risiko.

5. Pembuatan SOP yang mencakup semua kegiatan yang berkaitan dengan bisnis proses penyusunan Laporan Keuangan di Kementerian Keuangan.

6. Diperlukan peningkatan pembinaan SDM untuk lebih memahami PP Nomor 71 tahun 2010

7. Diperlukan pengelolaan persediaan yang memadai, terutama terkait Direktorat Jenderal Bea dan Cukai. Mengingat persediaan Bea Cukai cukup banyak. 
8. Direkomendasikan adanya penatausahaan Laporan Piutang Perpajakan.

9. Direkomendasikan adanya penatausahaan piutang PBB dan pelunasannya.

10. Direkomendasikan DJPB dan DJBC mempunyai tim gabungan untuk membuat mekanisme penagihan untu meminimalisir potensi tidak tertagihnya piutang bea masuk.

11. Direkomendasikan pembuatan aplikasi yang bisa mengetahui data-data dari lalu lintas Satuan Kerja. Sehingga kita dapat mencerminkan posisi asset yang sesungguhnya.

12. Direkomendasikan penambahan aplikasi KDP karena aplikasi SAIBA dan SIMAK untuk KDP menimbulkan masalah selisih.

13. Disarankan adanya kebijakan tersendiri karena titik kritis akrualisasinya sendirisendiri yaitu, Pendapatan BLU, Pendapatan Pajak, Pendapatan Bea Cukai, dan Pendapatan Bea Lelang

14. Disarankan sosialisasi kebijakan akuntansi dan aplikasi baru tidak berbenturan dengan periode berakhirnya penyusunan laporan keuangan.

15. Materi diklat ditambah dengan materi motivasi yang merubah paradigma lama menjadi akrual penuh yang lebih intens.

16. Pemberian reward misalnya kunjungan karya ke luar negeri guna meningkatkan motivasi dan menambah wawasan bagi para penyusun laporan keuangan di Kementerian Keuangan.

17. Terkait peraturan yang mengatur pos penyusutan, amortisasi, dan deplesi sebaiknya sudah mulai dipersiapkan agar pada saat aplikasi software terkait penyusutan disosialisasikan oleh Kementerian Keuangan, dapat langsung dilaksanakan.

18. Petunjuk teknis terkait penerapan akuntansi berbasis akrual yang belum detail segera di buat.

19. Adanya penertiban pencatatan peristiwa akuntansi dan penambahan aplikasi untuk akun-akun yang masih bermasalah agar data yang terkompilasi valid.

20. UAPA merupakan gerbong terakhir penyusunan Laporan keuangan sehingga membutuhkan kevalidan data yang terkumpul .
21. Saran untuk penelitian berikutnya diharapkan menggunakan teori Perubahan Pasca Kondisi Implementasi Basis Akrual (Syahril dan Devi, 2018) dan Teori Peran UAPA (Syahril dan Devi, 2018).

\section{Daftar Pustaka}

Halim, A., \& Kusufi, M. S. (2016). Teori, Konsep, dan aplikasi Akuntansi Sektor Publik. Jakarta: Salemba Empat.

Agustiawan, N. T., \& Rasmini, N. K. (2016). Pengaruh Sistem Berbasis Akrual, TI, Dan SPIP Pada Kualitas Laporan Keuangan Dengan Kompetensi SDM Sebagai Moderasi. E-Jurnal Ekonomi dan Bisnis Universitas Udayana.

Ahmad, N. N. (2016). Investigating the factors influencing users' resistance towards accrual accounting. Procedia Economics and Finance, 35, 17-26.

Arfan, I. (2005). Akutansi Keperilakuan. Jakarta : Salemba Empat.

Kamayanti, A. (2016). Metodologi Penelitian Kualitatif Akuntansi. Jakarta: Seri Media dan Literasi, 131-147.

Putra, I. W. G. Y. D., \& Ariyanto, D. (2015). Faktor-faktor yang Mempengaruhi Penerapan Standar Akuntansi Pemerintahan Berbasis Akrual. E-Jurnal Akuntansi, 14-32.

Azmi, A. H., \& Mohamed, N. (2014). Readiness of Malaysian public sector employees in moving towards accrual accounting for improve accountability: The case of Ministry of Education (MOE). Procedia-Social and Behavioral Sciences, 164, 106-111.

Todnem By, R. (2005). Organisational change management: A critical review. Journal of Change Management, 5(4), 369-380.

Creswell, J. W., \& Poth, C. N. (2016). Qualitative inquiry and research design: Choosing among five approaches. Sage publications.

Sari, E., \& Rohman, A. (2017). Analisis Faktor-Faktor Yang Mempengaruhi Tingkat Penerapan Akuntansi Akrual Pada Pemerintah (Studi Empiris pada Kantor 
Pelayanan Perbendaharaan Negara Kudus) (Doctoral dissertation, Fakultas Ekonomika dan Bisnis).

Mentu, E. P., \& Sondakh, J. J. (2016). Penyajian Laporan Keuangan Daerah Sesuai Peraturan Pemerintah No. 71 Tahun 2010 Tentang Standar Akuntansi Pemerintahan pada Dinas Pendapatan Daerah dan Dinas Sosial Prov. Sulut. Jurnal EMBA: Jurnal Riset Ekonomi, Manajemen, Bisnis dan Akuntansi, 4(1).

Kieso, D. E., Jerry, J. W., \& Terry, D. W. (2007). Intermediate Accounting Twelfth Edition. John Willey \& Sons.

Halim, A., \& Kusufi, M. S. (2014). Teori, Konsep, dan Aplikasi Akuntansi Sektor Publik-Dari Anggaran Hingga Laporan Keuangan, Dari Pemerintah Hingga Tempat Ibadah. Edisi 2. Jakarta: Penerbit Salemba Empat.

Laporan Keuangan Kementerian Keuangan Tahun Anggaran 2015.

Laporan Keuangan Kementerian Keuangan Tahun Anggaran 2016.

Lauma, E. B., Morasa, J., \& Kalangi, L. (2016). Analisis Penerapan Standar Akuntansi Pemerintah Terhadap Aset Tetap Pemerintah Daerah Kabupaten Bolaang Mongondow. Accountability, $5(2)$.

Lestari, P. (2014). Pra Kondisi Penerapan Akuntansi Berbasis Akrual (Studi Pada Pemerintah Kabupaten Rokan Hulu) (Doctoral dissertation, Universitas Gadjah Mada).

Maharsi, S. (2000). Pengaruh Perkembangan Teknologi Informasi Terhadap Bidang Akuntansi Manajemen. Jurnal Akuntansi \& Keuangan, 2(2), 127-137.

Alam, M. (2006). The interaction amongst reform drivers in governmental accounting changes. Journal of Accounting \& Organizational Change.

Lexy, J. M. (2009). Metodologi Penelitian Kualitatif: Rev Ed. Bandung: PT Remaja Rosdakarya.
Najati, I., \& Pituringsih, E. (2016). Implementasi Akuntansi Berbasis Akrual: Pengujian Determinan Dan Implikasinya Terhadap Kualitas Laporan Keuangan Kementerian/Lembaga. Lembaga Jurnal Akuntansi Universitas Jember, 14(1).

Neuman, W. L. (2013). Metodologi Penelitian Sosial: Pendekatan Kualitatif dan Kuantitatif (Edisi 7). Terjemahan Edina T. Sofia. Jakarta: PT. Indeks.

Granof, M. H., \& Wardlow, P. S. (2003). Core concepts of government and not-for-profit accounting. Wiley.

Harun, H., Van Peursem, K., \& Eggleton, I. (2012). Institutionalization of accrual accounting in the Indonesian public sector. Journal of Accounting \& Organizational Change, 8(3), 257-285.

Harun, H., \& Robinson, P. (2010). The adoption of accrual accounting in the Indonesian public sector. Research in Accounting in Emerging Economies, 10, 233-250.

Harun, H., Van-Peursem, K., \& Eggleton, I. R. (2015). Indonesian public sector accounting reforms: dialogic aspirations a step too far?. Accounting, Auditing \& Accountability Journal, 28(5), 706-738.

Hayati, H. (2014). Evaluasi Penyusunan Laporan Keuangan Kementerian ESDM (Tesis Pascasarjana Universitas UGM).

Herlina, H. (2013). Analisis Faktor-Faktor yang Mempengaruhi Kesiapan Pemerintahan Daerah Dalam Implementasi PP 71 tahun 2010 (Studi Empiris: Kabupaten Nias Selatan). Jurnal Akuntansi, 1(3).

Hyndman, N., \& Connolly, C. (2011). Accruals accounting in the public sector: A road not always taken. Management Accounting Research, 22(1), 36-45.

Putra, I. W. G. Y. D., \& Ariyanto, D. (2015). Faktor-faktor yang Mempengaruhi Penerapan Standar Akuntansi Pemerintahan Berbasis Akrual. E-Jurnal Akuntansi, 14-32.

Bastian, I. (2001). Akuntansi Sektor Publik di Indonesia, Pusat Pengembangan Akuntansi 
Fakultas Ekonomi. Universitas Gajah Mada. Yogyakarta.

Agustiawan, N. T., \& Rasmini, N. K. (2016). Pengaruh Sistem Berbasis Akrual, TI, Dan SPIP Pada Kualitas Laporan Keuangan Dengan Kompetensi SDM Sebagai Moderasi. E-Jurnal Ekonomi dan Bisnis Universitas Udayana.

Peraturan Menteri Keuangan. (2015). Peraturan Menteri Keuangan Nomor 234/PMK.01/2015 tentang Organisasi dan Tata Kerja Kementerian Keuangan.

Peraturan Menteri Keuangan. (2016). Peraturan Menteri Keuangan Nomor 222/PMK.05/2016 tentang Pedoman Penyusunan Laporan Keuangan Kementerian/Lembaga.

Pollack, J., \& Pollack, R. (2015). Using Kotter's eight stage process to manage an organisational change program: Presentation and practice. Systemic Practice and Action Research, 28(1), 5166.

Primasari, L. (2011). Proses Manajemen Perubahan Dalam Program Transformasi Bisnis: "Studi Kasus PT Tripatra Pada Tahun 2010-2011" (Tesis Universitas Indonesia).

Reck, J. L., Lowensohn, S. L., Wilson, E. R., \& Hay, L. E. (2013). Accounting for governmental \& nonprofit entities. New York, NY: McGraw-Hill/Irwin.

Nomor, P. P. (71). Tahun 2010 tentang Standar Akuntansi Pemerintahan. Presiden Republik Indonesia, Jakarta.

Kusuma, M. I. Y., \& Fuad, F. (2013). Analisis Faktor-faktor yang Mempengaruhi Tingkat Penerapan Akuntansi Akrual pada Pemerintah (Doctoral dissertation, Fakultas Ekonomika dan Bisnis).

Siegel, G., \& Ramanauskas-Marconi, H. (1989). Behavioral accounting. Thomson South-Western.

Soekanto, S. (2009). Sosiologi Suatu Pengantar. Edisi Baru. Jakarta : Rajawali Pers.

Sugiyono. (2016). Memahami Penelitian Kualitatif. Bandung: Alfabeta.

Yin, R. K. (1996). Studi Kasus: Desain dan Metode (penerjemah: M. Djauzi Mudzakir). Jakarta: RajaGrafindo Persada.

Purwanto, W. (2015). Kajian Penerapan Akuntansi Berbasis Akrual pada Pemda DIY (Doctoral dissertation, Universitas Gadjah Mada).

Wyk, H. A. V. (2007). Is the transformation of public sector financial reporting in South Africa's provincial governments on track?. Meditari Accountancy Research, 15(2), 65-75. 
Syahril Djaddang, Devi Kusumawardhani, Nurmala Ahmar : Pasca Kondisi Implementasi Akuntansi Berbasis Akrual Pada Penyusunan Laporan Keuangan Kementerian Keuangan ... 